\title{
DNAzyme as an efficient tool to modulate invasiveness of human carcinoma cells
}

\author{
Magdalena Wiktorska1, Izabela Papiewska-Pająk', Andrzej Okruszek², Izabela Sacewicz- \\ Hofman ${ }^{1}$ and Jolanta Niewiarowska1 ${ }^{\bowtie}$
}

'Department of Molecular and Medical Biophysics, Medical University of Łódź, Poland; 2Department of Bioorganic Chemistry, Centre for Molecular and Macromolecular Studies, Polish Academy of Sciences, Lodz, Poland, and Institute of Technical Biochemistry, Technical University of Lodz, Poland

In this study we evaluated efficiency of DNAzymes to modulate motility of cancer cells, an important factor in the progression and metastasis of cancers. For this purpose we targeted $\beta 1$ integrins that are predominant adhesive receptors in various carcinoma cell lines (CX1.1, HT29, LOVO, LS180, PC-3). To evaluate invasiveness of cancer cells, we used a transwell migration assay that allowed analyzing chemotactic migration of colon carcinoma cell lines across an ECM-coated membrane. Their adhesive properties were also characterized by the analysis of adhesion to fibronectin, laminin and collagen. In addition, the expression of major integrin subunits, selected intact $\beta 1$ integrins, and other adhesive receptors (ICAM, E-selectin, uPAR) was analyzed by flow cytometry. Inhibition of $\beta 1$ integrin expression by DNAzyme to $\beta 1$ mRNA almost abolished the invasiveness of the CX1.1, HT29, LS180, LOVO and PC-3 cells in vitro. These data show that DNAzymes to $\beta 1$ integrin subunit can be used to inhibit invasiveness of carcinoma cells.

Keywords: DNAzyme, integrin, cancer cells

Received: 19 August, 2009; revised: 11 May, 2010; accepted: 10 June, 2010; available on-line: 19 August, 2010

\section{INTRODUCTION}

Local invasion of the host tissue and metastasis are hallmark features of cancer progression (Hanahan \& Weinberg, 2000) and understanding the tumor cell motility is important for therapeutic targeting of cancer progression (Quaranta, 2002). Invasion of tumor cells into the host tissue is regulated by the matrix microenvironment at the tumor-host tissue interface (Liotta \& Kohn, 2001; Quaranta, 2002). Migration of cancer cells is likely initiated by cytokines and growth factors released by the host tissue that attract the malignant tumor cells to invade it (Fidler et al., 1998; Kassis et al., 2001; Radisky et al., 2001). Degradation and remodeling of the peri-tumor ECM is considered a necessary step in local tumor invasion (Stetler-Stevenson et al., 1993; Egeblad \& Werb, 2002).

In our recent works, we downregulated $\beta 1$ integrins in several cell lines (Papiewska-Pajak \& Antoszczyk, 2006) and provided evidence that DNAzymes can be useful gene-inactivating agents to control expression of membrane proteins (Haier et al., 1998; Sawhney et al., 2002). DNAzymes are commonly used in cancer therapy (Dass et al., 2008; Chan \& Khachigian, 2009). DNAzymes to $\beta 1$ and $\beta 3$ mRNAs appeared to be strong inhibitors of angiogenesis in in vitro assays that might ultimately provide a therapeutic means to inhibit angiogenesis in vivo.

Integrin receptors play a primary role in motility of cancer cells. They are involved not only in the physical tethering of the cells to the matrix, but also in transmitting signals in both directions in the cells (outside-in, and inside-out). Changes in expression of integrins induced by carcinogenesis are complex (Goel et al., 2008): (a) expression levels of numerous integrins can be upregulated during cancer progression (Hodgkinson et al., 2000; Yuan et al., 2000; Ise et al., 2001; Schaffert et al., 2001); (b) in some cells carcinogenesis is associated with a switch in integrin expression, for example, the major integrins $\alpha 5 \beta 1$ and $\alpha 6 \beta 1$ on normal hepatocytes are replaced by $\alpha 1 \beta 1, \alpha 2 \beta 1$ and $\alpha 3 \beta 1$, abundantly expressed in cancer cells (Kawakami-Kimura et al., 1997; Giannelli et al., 2001; Torimura et al., 2001). This switch of integrin expression is associated with the acquisition of migratory capacity, suggesting an important role of these integrins in cancer cell motility. Furthermore, several growth factors that are abundantly expressed in the tumor microenvironment are considered potent stimulators of integrin expression (Kagami et al., 1996; Smida et al., 2000).

The purpose of this study was to test whether DNAzyme to $\beta 1$ integrin subunit can inhibit pathogenic cellECM interactions and thus block invasion of cells in in vitro assays.

\section{EXPERIMENTAL PROCEDURES}

Materials. Monoclonal antibodies to integrins were from Dako, BD-PharMingen, Serotec Inc., Chemicon International Inc., American Diagnostica Inc.

Synthesis of DNAzyme to $\beta 1$ mRNA. DNAzyme was chemically synthesized on solid support using an ABI-394 DNA Synthesizer as described before (Cierniewski et al., 1995). This particular DNA sequence (5' CAAGGTGAGg $\mathrm{g}_{2} \mathrm{c}_{3} \mathrm{t}_{4} \mathrm{a}_{5} \mathrm{~g}_{6} \mathrm{c}_{7} \mathrm{t}_{8} \mathrm{a}_{9} \mathrm{c}_{10} \mathrm{a}_{11} \mathrm{a}_{12} \mathrm{c}_{13} \mathrm{~g}_{14} \mathrm{a}_{15}$ AATAGAAG 3') was used by us previously to analyze enzymatic activity, specificity, exonuclease resistance, and ability to inhibit expression of $\beta 1$ integrins in endothelial cells (Cieslak et al., 2002). To increase the stability of the

e-mail: jolanta.niewiarowska@umed.lodz.pl

Abbreviations: BSA, bovine serum albumin; DNAzyme, DNA-cleaving deoxyribozyme; ECM, extracellular matrix; FBS, fetal bovine serum; FITC, fluorescein isothiocyanate; ICAM, intercellular adhesion molecule; PE, phicoerytrin; UPAR, urokinase plasminogen activator receptor. 
DNAzyme, oligonucleotides modified with 2'-O-methyl groups were introduced at both the $5^{\prime}$ and $3^{\prime}$ ends. Thus, the analogue of $\beta 1 \mathrm{DE}$ called $\beta 1 \mathrm{DE}-\mathrm{OME}$ was used throughout this work. In addition, inactive DNAzyme, $\beta 1 \mathrm{DE}-\mathrm{OME}_{\mathrm{IN}}$ with the designed structure based on the inactive antisense oligodeoxynucleotide $\beta 1(358-375)$ (TTCTTTATA $g_{1} g_{2} c_{3} t_{4} a_{5} g_{6} c_{7} t_{8} a_{9} c_{10} a_{11} a_{12} c_{13} g_{14} a_{15}$ TCTTTGGAG) was synthesized and used in control experiments. All deoxyribooligonucleotides and DNAzymes were purified by semipreparative RP-HPLC (Hamilton PRP1) (to $98 \%$ ) and their purity was confirmed by polyacrylamide gel electrophoresis under denaturing conditions.

Carcinoma cell lines and culture conditions. Human colon cancer cell lines (CX1.1, HT29, LOVO, LS180) and human prostate carcinoma cell line (PC-3) were obtained from the Ludwik Hirszfeld Institute of Immunology and Experimental Therapy, Polish Academy of Sciences (Wroclaw, Poland). Colon carcinoma cells were cultured and maintained in the MEM- $\alpha$ medium supplemented with $10 \%$ fetal bovine serum, streptomycin $(100 \mu \mathrm{g} / \mathrm{ml})$, penicillin (100 units $/ \mathrm{ml})$, L-glutamine (2 mM). PC-3 cells were cultured and maintained in DMEM supplemented with $10 \%$ fetal bovine serum, streptomycin $(100 \mu \mathrm{g} / \mathrm{ml})$, penicillin (100 units $/ \mathrm{ml})$. All cell cultures were maintained at $37^{\circ} \mathrm{C}$ in the presence of $5 \% \mathrm{CO}_{2}$. For experiments, cells were transferred to 6 -well dishes and used at $70 \%$ confluency in DMEM or MEM- $\alpha$ supplemented as above. DNAzymes were mixed with LipofectAMINE ${ }^{T M}$ Reagent (Gibco BRL ${ }^{\circledR}$ ) suspended in Opti-MEM reduced medium $(5 \mu \mathrm{g} / \mathrm{ml})$ containing $5 \mathrm{mM} \mathrm{MgCl}$ and diluted with the corresponding medium to obtain the final concentration of $0.5 \mu \mathrm{M}$. Transfection was performed according to the manufacturer's protocol. After incubation for $24 \mathrm{~h}$, cells were detached with trypsin/EDTA and used for experiments. Cell viability was determined microscopically by Trypan Blue exclusion and only cell cultures having less than $1 \%$ dead cells were included into the study.

Flow cytometry. Cell membrane expression of $\alpha 4$, $\alpha 5, \alpha 6, \alpha v, \beta 1, \beta 3$, and $\beta 4$ integrin subunits, $\alpha 2 \beta 1$ and $\alpha 5 \beta 1$ as well as uPAR, E-selectin and ICAM was measured by flow cytometry. Subconfluent cells were harvested with trypsin/EDTA and washed with FBS-free MEM- $\alpha$ or DMEM. Then, cells $\left(1 \times 10^{6}\right)$ were suspended in the medium containing $1 \%$ bovine serum albumin (BSA) and incubated for $30 \mathrm{~min}$ at $4{ }^{\circ} \mathrm{C}$ in the dark with FITC- or PE-conjugated monoclonal antibodies to the surface receptors. After double washing with $1 \% \mathrm{BSA} /$ PBS, the cells were fixed by mixing the sedimented cells with $1 \%$ paraformaldehyde in PBS and resuspended in FACS Flow liquid. Cell fluorescence was measured with a FACScan flow cytometer (Becton Dickinson, Mountain View, CA, USA). The data were analyzed with PC Lysis II software.

Western blotting. Subconfluent cells were grown in the presence or absence of $\beta 1 \mathrm{DE}$-oME or $\beta 1 \mathrm{DE}-\mathrm{oME}_{\mathrm{IN}}$ for $6 \mathrm{~h}$. After further incubation for $12 \mathrm{~h}$ in fresh medium supplemented with $5 \%$ FCS the cells were washed with PBS and lysed in M-PER Mammalian Protein Extraction Reagent (Pierce) supplemented with protein inhibitor cocktail (Complete $\left.{ }^{\mathrm{TM}}\right)$. Total protein extract $(30 \mu \mathrm{g})$ from cells transfected with $\beta 1 \mathrm{DE}-\mathrm{OME}, \beta 1 \mathrm{DE}-\mathrm{OME} \mathrm{IN}_{\mathrm{IN}}$ or mock-transfected was boiled with $5 \times$ concentrated sample buffer with 2-mercaptoethanol and separated by SDS/PAGE and electroblotted onto Nitrocellulose membranes (BIO-RAD). The membranes were blocked in PBS containing 5\% skimmed milk and $0.05 \%$ Tween 20. Human $\beta 1$ integrin subunit was detected with rabbit polyclonal antibody (Santa Cruz Biotechnology), $\beta$-actin with rabbit polyclonal antibody (Abcam). Immunodetection was accomplished using the enhanced chemiluminescence kit (ECL Kit, Pierce), then films were scanned and protein bands quantitated using the GelImage system (Pharmacia LKB). To quantify the densitometric scans, the background was subtracted and the area for each protein peak was determined.

Adhesion assay. Wells of F8 Maxisorp loose NuncImmuno $^{\mathrm{TM}}$ modules (Nunc $^{\mathrm{TM}}$ brand products) were coated with $50 \mu \mathrm{l}$ of fibronectin, laminin or collagen type I used at $10 \mu \mathrm{g} / \mathrm{ml}$ in TBS $(0.02 \mathrm{M}$ Tris $/ \mathrm{HCl}$, $0.15 \mathrm{M} \mathrm{NaCl}, \mathrm{pH}$ 7.6). Proteins were allowed to bind for $2 \mathrm{~h}$ at $37^{\circ} \mathrm{C}$ before the wells were rinsed twice with TBS and blocked for $1.5 \mathrm{~h}$ at $37^{\circ} \mathrm{C}$ in a humidified $5 \%$ $\mathrm{CO}_{2}$ atmosphere with $200 \mu \mathrm{l}$ of $1 \%$ heat-denatured BSA in TBS, $\mathrm{pH} 7.5$, containing $0.1 \mathrm{mM} \mathrm{CaCl}_{2}$. Cells were harvested and added to the wells at $1.5 \times 10^{5}$ cells $/ 0.15$ $\mathrm{ml}$ of DMEM for $1.5 \mathrm{~h}$ at $37^{\circ} \mathrm{C}$ in $5 \% \mathrm{CO}_{2}$ atmosphere. Cells that did not adhere were removed by gentle washing with TBS containing $0.1 \mathrm{mM} \mathrm{CaCl}, \mathrm{pH} 7.5$. The total cell-associated protein was determined by dissolving the attached cells directly in the micro-titer wells with $200 \mu \mathrm{l}$ of Pierce BCA (bicinchonImic acid) protein assay reagent. The modules were incubated for $30 \mathrm{~min}$ at $37^{\circ} \mathrm{C}$, and the absorbance of each well was determined at $562 \mathrm{~nm}$ with a microplate reader (BioKinetics Reader EL340, Bio-Tek Instruments).

Chemoinvasion assay. Invasion assays were conducted on polycarbonate filters, $8 \mu \mathrm{m}$ (Transwell ${ }^{\circledR}$ Cos$\left.\operatorname{tar}^{(\mathbb{R}}\right)$. The filters were coated with basement membrane Matrigel $^{\text {TM }}(25 \mu \mathrm{g} /$ filter). The matrigel was spread on to the filters, dried under a hood, and reconstituted with serum-free medium. Cells were harvested with trypsin/ EDTA and diluted, depending upon the type of cells tested, in either MEM- $\alpha$ or DMEM with $0.1 \%$ BSA to the final density of $2 \times 10^{6}$ cells $/ \mathrm{ml}$, and $50 \mu \mathrm{l}$ of the cell suspension was added to the upper chamber. Conditioned medium was obtained by incubating mouse fibroblasts (3T3) for $24 \mathrm{~h}$ in serum-free medium in the presence of ascorbate $(50 \mathrm{mg} / \mathrm{l})$. This medium was used as a source of chemoattractants and placed in the lower compartment of the chambers. The assembled chambers were incubated for $6 \mathrm{~h}$ at $37^{\circ} \mathrm{C}$ and $5 \% \mathrm{CO}_{2}$. Then, the cells on the upper surface of the filter were completely removed by wiping with a cotton swab. The filters were fixed in methanol, cells were stained with Mayer's hematoxylin and eosin, and counted from the lower surface of the filter.

Data analysis. All values are expressed as mean \pm S.D. and were compared with controls. Significant difference was taken for $P$ values less than 0.05 .

\section{RESULTS AND DISCUSSION}

Invasion and metastasis are important determinants in the progression of cancer, and the motility of cancer cells is dependent on their interactions with the microenvironment (Liotta \& Kohn 2001; Quaranta, 2002). The expression levels of various integrins are up-regulated during cancer progression and the altered cell-ECM interactions are considered important in the invasion and metastasis of tumor cells (Quaranta, 2002). Therefore, in preliminary experiments an analysis of surface membrane integrin expression was performed by flow cytometry in a variety of human colon malignant cell lines. The $\beta 1$ subfamily of integrins plays a crucial role in cell adhesion 


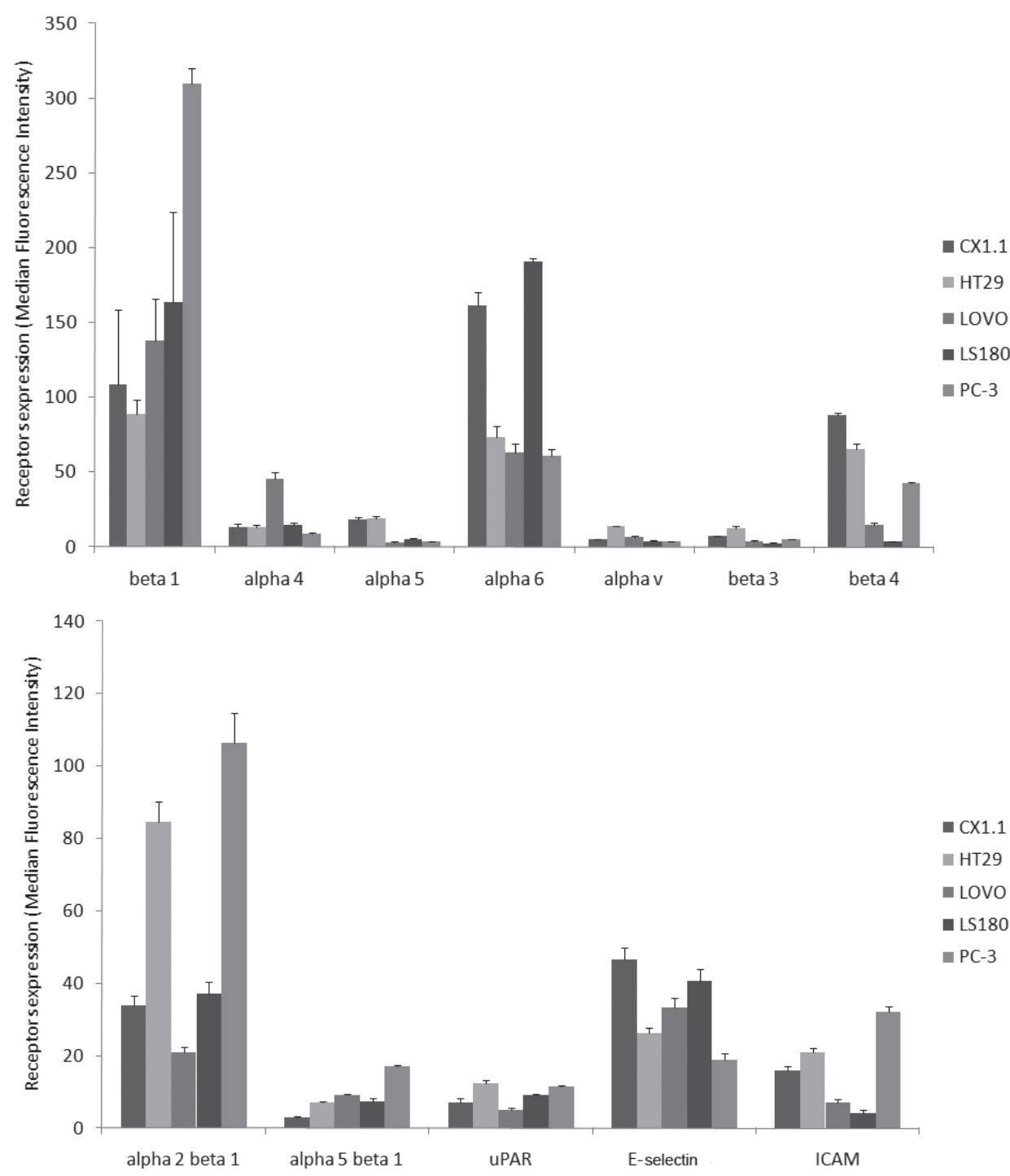

Figure 1. Cell membrane expression of selected integrin subunits and intact adhesive receptors in human cancer cells Colon carcinoma cell lines (CX1.1, HT29, LOVO, LS180) were stained with monoclonal antibodies to $a$ and $\beta$ subunits of integrins (A) or specific to intact $\alpha 2 \beta 1$ and $\alpha 5 \beta 1$ as well as uPAR, E-selectin and ICAM (B). In parallel, prostate cancer cells PC-3 were analyzed. Fluorescence intensity of the staining was measured with a FACScan flow cytometer and expressed as Median Fluorescence Intensity.

and invasiveness (Simon-Assmann et al., 1994; Yao et al., 2007). Because the $\beta 1$ integrin subfamily plays a crucial role in early stages of angiogenesis and invasiveness of cancer cells (Giannelli et al., 2002; Zeng et al., 2006), we also characterized the cell lines with respect to $\beta 1$ integrin subunit expression. There was high expression of $\beta 1$ integrin subunit (Fig. 1A), which appeared to be mostly in a complex with $\alpha 2$ forming a primary collagen receptor $\alpha 2 \beta 1$. The high expression of $\alpha 2 \beta 1$ in human colon carcinoma cells was then confirmed by FACS analysis using monoclonal antibody specific to the intact $\alpha 2 \beta 1$ receptor (Fig. 1B).

All human malignant colon cells (CX1.1, HT29, LOVO and LS180) and the prostate PC-3 cells showed high expression of $\alpha 6$. Since the expression of $\beta 4$ integrin subunit was also increased (CX1.1, HT29, PC-3), $\alpha 6 \beta 4$ is likely a major integrin on these cells (Fig. 1A). The ligand of integrin $\alpha 6 \beta 4$ is laminin-5, a major structural component of the basement membrane of epithelial tissues (Jones et al., 1998; Borradori \& Sonnenberg, 1999). Indeed, the binding of $\alpha 6 \beta 4$ integrin and laminin-5 is prerequisite to adhesion, migration, and morphogenetic events of some epithelial cells. Thus, the $\alpha 6 \beta 4$ integrin is strongly involved in tumor cell invasion (Lohi, 2001; Mercurio et al., 2001). E-selectin and uPAR are also implicated in tumor cell metastasis (Felding-Habermann et al., 1992; Kruskal et al., 2007; Dass et al., 2008; Kielosto et al., 2009). This is why we decided to check the level of these proteins in human malignant colon and prostate cancer cells (Fig. 1A, 1B). The colon carcinoma cell lines expressed similar and substantial levels of E-selectin and uPAR (Fig. 1B).

Previous studies showed that poorly and highly livermetastatic colon carcinoma cell lines showed various patterns of adhesion to various substrates and different integrin-mediated adhesion to extracellular matrix (Haier et al., 1998). Adhesion of carcinoma cells was mediated by different integrins depending on the ECM components. Some of these receptors, for example $\alpha 5 \beta 1$, were significantly associated with the carcinogenesis and differentiation of colorectal carcinomas, but not with their lymph node metastasis, and the expression level was sug- 


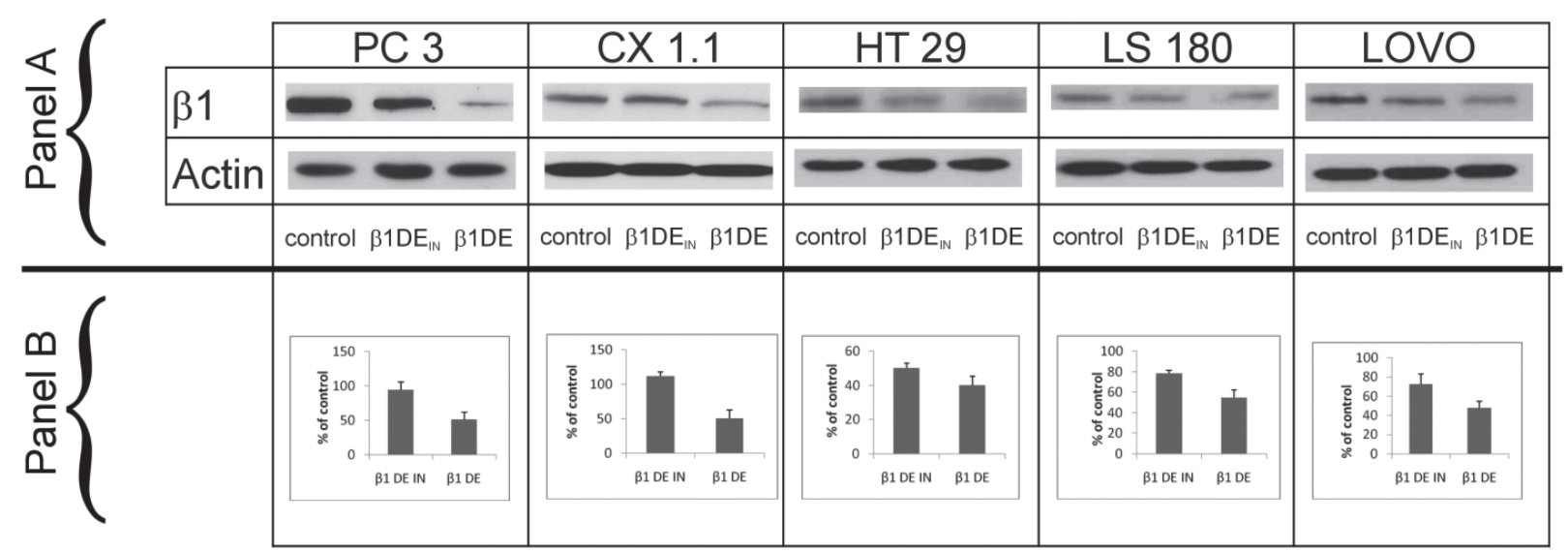

Figure 2. Effect of DNAzyme ( $\beta 1 D E)$ on $\beta 1$ integrin subunit level in human colon carcinoma and prostate cancer cells

Panel A shows expression of $\beta 1$ integrin subunit in PC-3, CX1.1, HT29, LS180, and LOVO analyzed by Western blotting. Cells were treated with nonactive or active DNAzyme, lyzed, proteins were separated by SDS/PAGE, transfered onto nitrocellulose membrane and stained with specific anti- $\beta 1$ antibodies (Panel A). Then, the membranes were scanned and levels of $\beta 1$ integrin subunit expressed as mean \pm S.D. for $2-5$ independent experiments (Panel B).
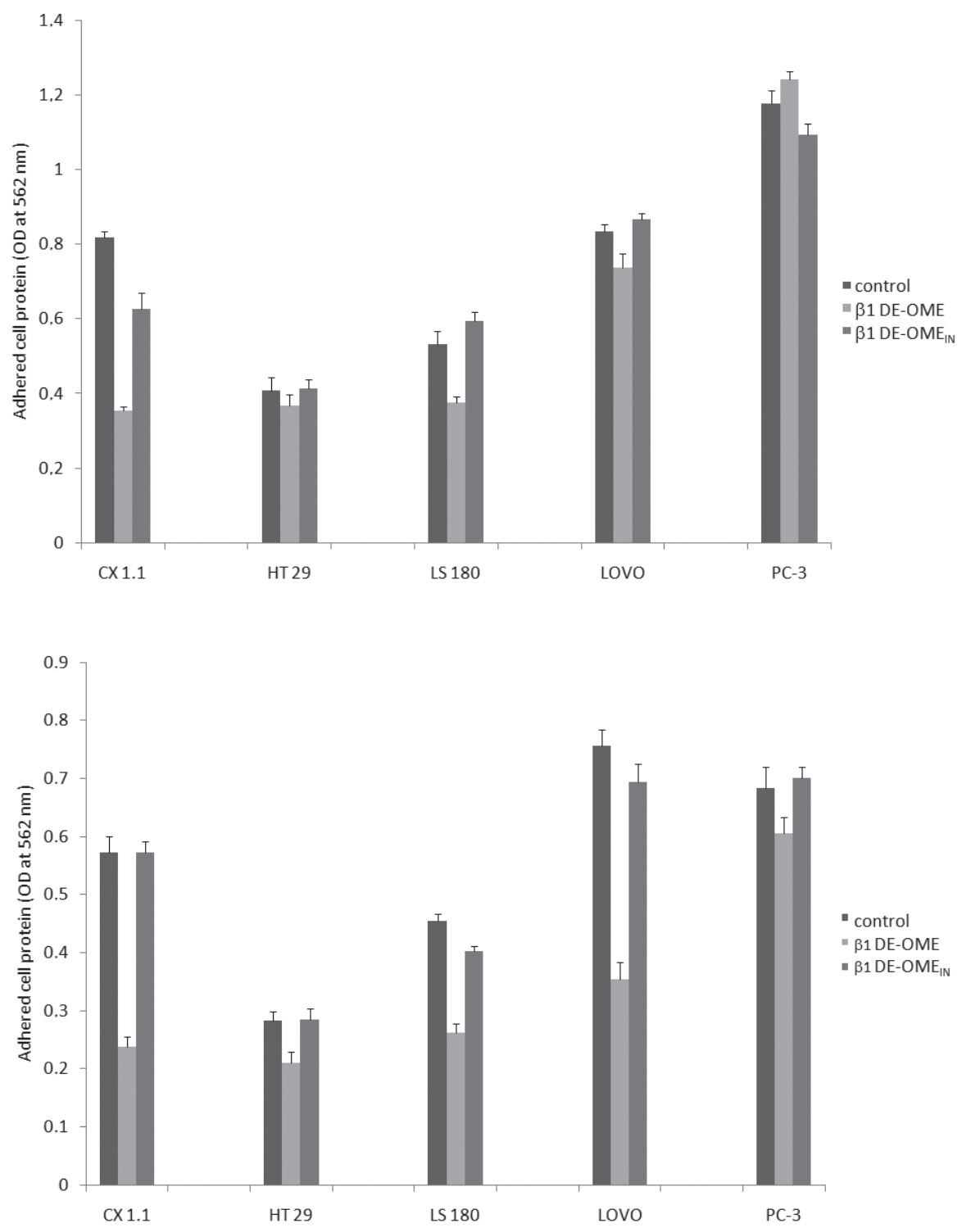


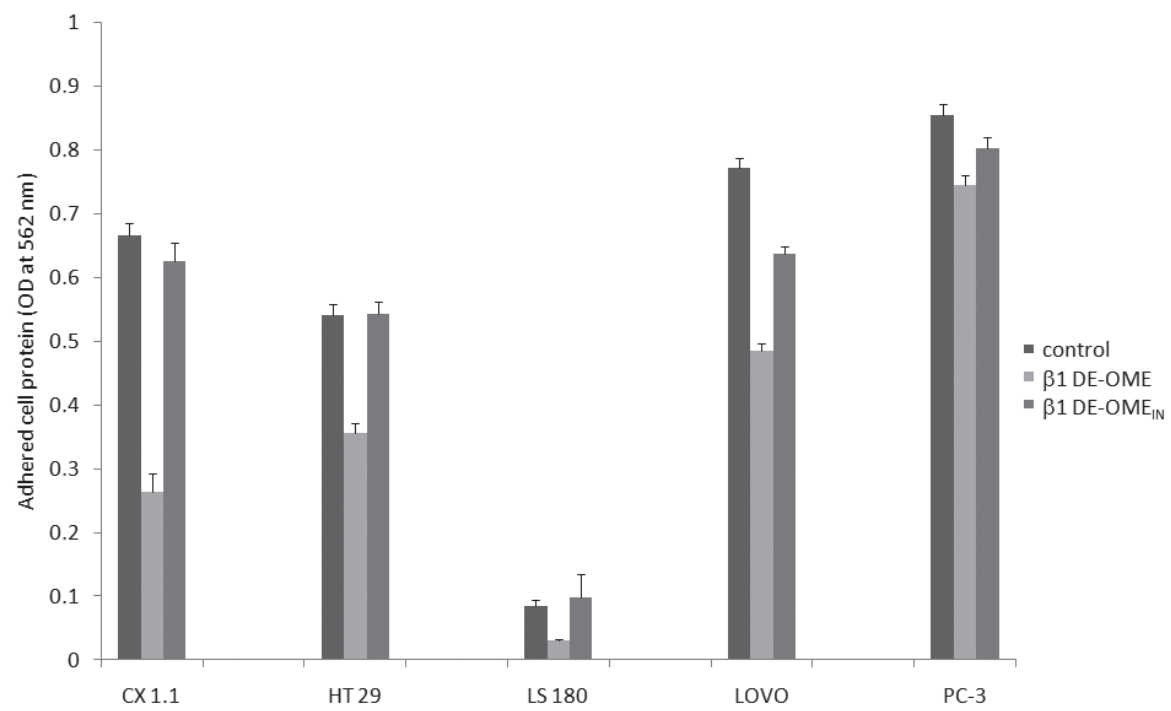

Figure 3. Effect of DNAzyme ( $\beta 1 D E$ ) on adhesion of human colon and prostate cancer cells

Adhesion of CX1.1, HT29, LS180, LOVO cells after incubation with $0.5 \mu \mathrm{M}$ of $\beta 1 \mathrm{DE}-\mathrm{OMe}$ for $24 \mathrm{~h}$ was evaluated using plastic wells coated with fibronectin (A), laminin (B) or collagen type I (C). The adhesion, relative to that of untreated cells or cells treated with inactive DNAzyme, was determined based on the measurement of cell protein recovered after solubilization by $\mathrm{NaOH}$ of cells adhering to plastic wells and determined with BCA reagent.

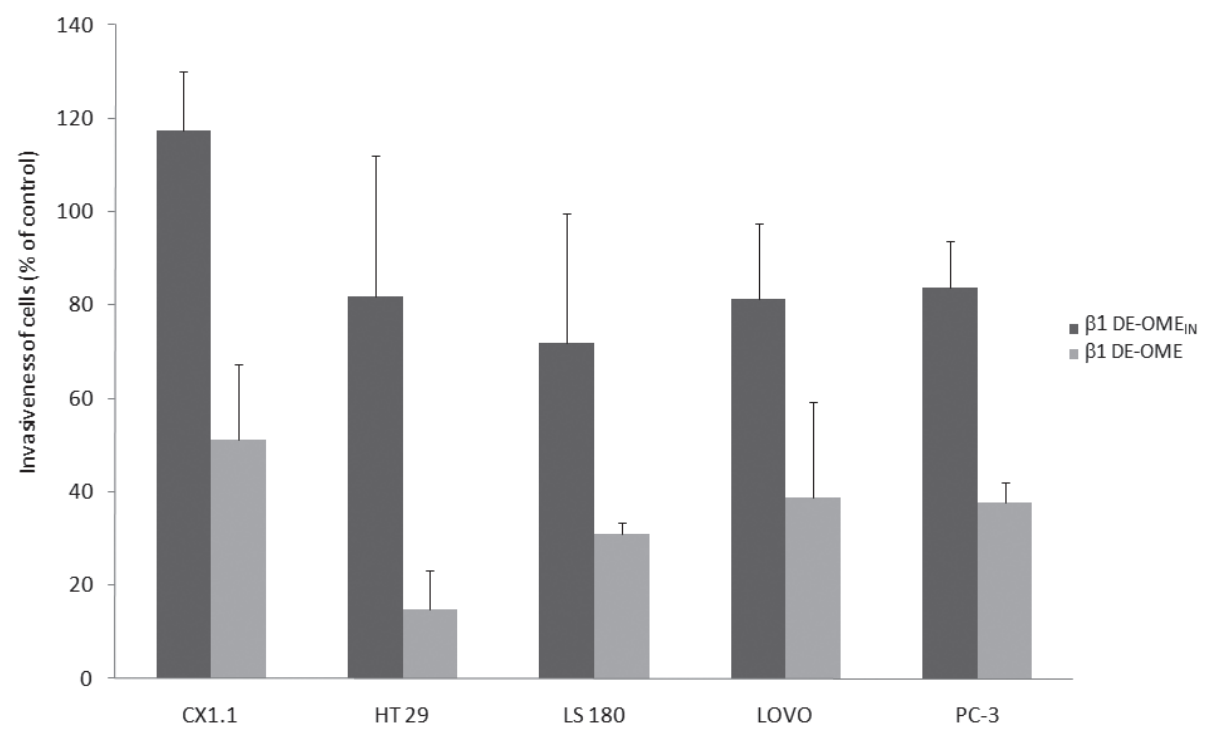

Figure 4. Effect of DNAzyme ( $\beta 1 D E)$ on invasive properties of human colon carcinoma and prostate cancer cells

CX1.1, HT29, LS180, and LOVO cells were treated with inactive or active DNAzyme to $\beta 1$ mRNA, allowed to invade Matrigel ${ }^{\mathrm{TM}}$ and migrate into the lower part of the filter. Cells on the lower side of the filter were counted and their number was expressed in relation to control cells. (Cells treated with lipofectamine only).

gested to be a valuable indicator for the carcinogenesis and progression of colorectal carcinomas. Because of the great involvement of integrins in cancer metastasis, various potential strategies for inhibiting these receptors have been developed, for example specific antibodies (Chen et al., 2008), receptor antagonists (Qian et al., 2005 ) or disintegrins (Oliva et al., 2007). The $\beta 1$ integrin subfamily, particularly $\alpha 1 \beta 1, \alpha 2 \beta 1, \alpha 4 \beta 1, \alpha 5 \beta 1, \alpha 6 \beta 1$ and $\alpha v \beta 1$, have been reported to be the most important ones for the interaction of colon carcinoma cells with ECM in the host organs for organ-specific metastasis (Sawhney et al., 2002). To use the $\beta 1$ subfamily as an anticancer therapy target, inhibitory antibody (Park et al., 2006), nonpeptidic antagonist (Maglott et al., 2006) or anti-tumor protein (Sabherwal et al., 2006) have been ex- amined. In the following experiments we attempted to evaluate the invasiveness of several colon carcinoma cell lines and a prostate cancer cell line after treatment with the DNAzyme to $\beta 1 \mathrm{mRNA}$. In our recent work we found DNAzyme approaches very efficient in inhibition of integrin expression in endothelial cells (Cieslak et al., 2002). The DNAzyme used in this work was previously characterized in terms of its specificity, cellular stability and the mechanism by which it blocked the $\beta 1$ integrin subunit synthesis (Cieslak et al., 2002). The structural and catalytic properties of this DNAzyme were described in detail in previous work (Cieslak et al., 2003). To reduce $\beta 1$ subunit expression, colon carcinoma cells and prostate cancer cells were treated with $0.5 \mu \mathrm{M} \beta 1 \mathrm{DE}$ OME for $24 \mathrm{~h}$ and tested by Western blotting, also in 


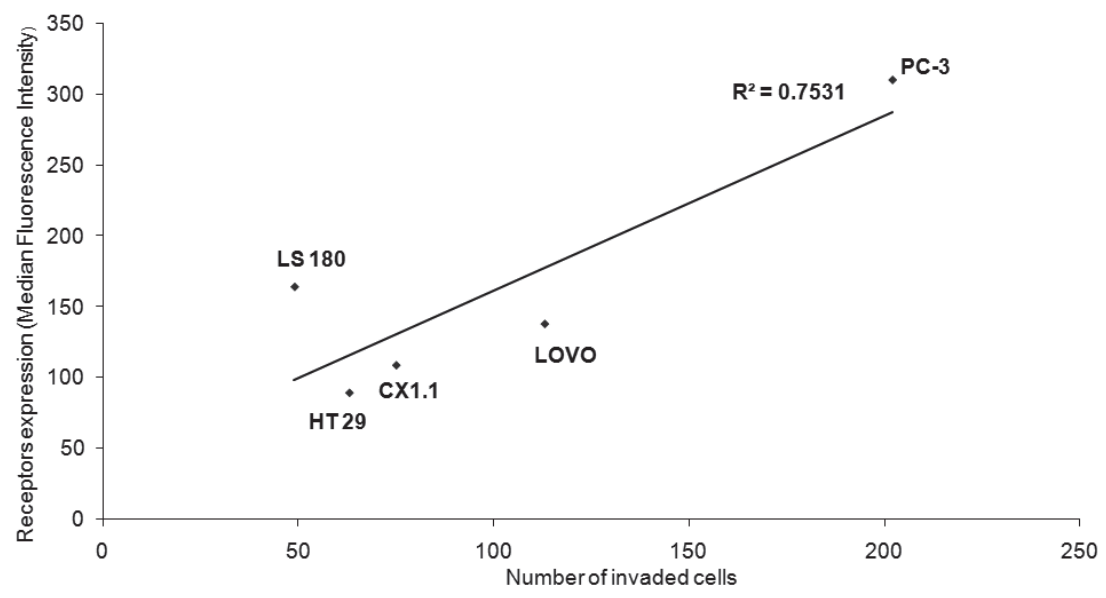

A

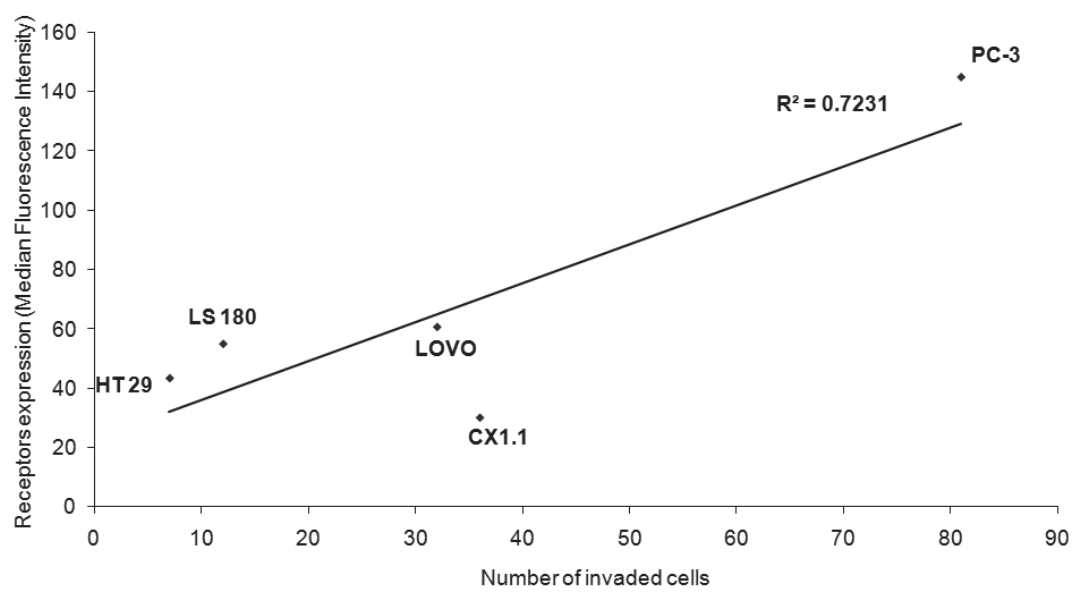

Figure 5. Correlation of invasiveness of cancer cells with their expression of $\beta 1$ integrin

Invasiveness was evaluated by counting cells on polycarbonate filters covered with Matrige ${ }^{\mathrm{TM}}$ while expression of $\beta 1$ integrin subunit was evaluated by FACS and expressed as Median Fluorescence Intensity. Cells were tested before (A) and after (B) treatment with $\beta 1 D E$.

adhesion and invasiveness assays. Untreated cells or cells incubated with an inactive DNAzyme under the same conditions served as controls. The Western blot analysis revealed that $\beta 1 \mathrm{DE}-\mathrm{OME}$ downregulated the expression of the $\beta 1$ integrin subunit at the protein level (Fig. 2A). The highest inhibition was observed in the CX1.1 and PC-3 cell lines (Fig. 2B). As shown in Fig. 3, treatment of colon carcinoma cells with $31 \mathrm{DE}-\mathrm{OME}$ partly inhibited cell adhesion to fibronectin (Fig. 3A), laminin (Fig. 3B), and collagen (Fig. 3C). CX1.1, HT29, LOVO, and LS180 cells showed similarly reduced adhesive properties towards all three proteins. Among the colon carcinoma cells, CX1.1 cells appeared to be the most sensitive to $\beta 1 \mathrm{DE}-\mathrm{OME}$, showing adhesion to all three proteins decreased by approx. $60 \%$. It is noteworthy that $\beta 1 \mathrm{DE}-\mathrm{OME}$ hardly affected the adhesion of PC-3 cells to fibronectin (Fig. 3A).

Then we used the Transwell ${ }^{\mathbb{B}}$ migration assay through a polycarbonate membrane coated with Matrigel to compare the effect of the DNAzyme to $\beta 1$ mRNA on the invasion of colon carcinoma cell lines and the highly invasive PC-3 cells. In the invasion assay the culture medium obtained after treatment of 3T3 cells with ascorbate, and thus enriched in growth factors, was used as the source of chemotactic migratory stimuli. The downregulation of $\beta 1$ integrins in colon carcinoma cells, particularly CX1.1, HT29, decreased the number of invading cells by $49 \%$ and $85 \%$, respectively (Fig. 4). Also LS180 (minimally invasive colon carcinoma cells) and LOVO (highly invasive colon carcinoma cells), as well as PC-3 (highly invasive prostate cancer cells) showed significantly reduced invasiveness upon treatment with the DNAzyme to $\beta 1$ mRNA. Interestingly, the invasiveness of PC-3 cells (Fig. 4) was much more sensitive to $\beta 1 \mathrm{DE}-\mathrm{OME}$ treatment than their adhesive properties (Fig. 3A, B, $\mathrm{C})$. We also found that the invasiveness of cancer cells was highly correlated with the expression of $\beta 1$ integrin subunit both before addition of the inhibitory DNAzyme (Fig. 5A; $\mathrm{R}^{2}=0.7531$ ) and afterwards (Fig. 5B; $\left.\mathrm{R}^{2}=0.7231\right)$.

These studies provide direct evidence that blocking $\beta 1$ integrin subunit synthesis by specific DNAzyme inhibited the adhesion and invasion of the carcinoma cell lines tested. These data confirme previous studies showing a central role for $\beta 1$ integrin in cancer cell motility and further demonstrate that DNAzymes can be used to investigate the role of $\beta 1$ integrin subunits in the invasiveness of malignant cells in vitro.

\section{Acknowledgements}

We thank Professor Czesław S. Cierniewski for careful reading and correction of the manuscript. 
This work was supported by KBN Projects: 502-16650 and N N401 121733.

\section{REFERENCES}

Borradori L, Sonnenberg AJ (1999) Structure and function of hemidesmosomes: more than simple adhesion complexes. Invest Dermatol 112: 411-418.

Chan CW, Khachigian LM (2009) DNAzymes and their therapeutic possibilities. Intern Med J 39: 249-251.

Chen Q, Manning CD, Millar H, McCabe FL, Ferrante C, Sharp C, Shahied-Arruda L, Doshi P, Nakada MT, Anderson GM (2008) CNTO 95, a fully human anti alphav integrin antibody, inhibits cell signaling, migration, invasion, and spontaneous metastasis of human breast cancer cells. Clin Exp Metastasis 25: 139-148.

Cierniewski CS, Babinska A, Swiatkowska M, Wilczynska M, Okruszek A, Stec W (1995) Inhibition by modified oligodeoxynucleotides of the expression of type-1 plasminogen activator inhibitor in human endothelial cells. Eur J Biochem 227: 494-499.

Cieslak M, Niewiarowska J, Nawrot M, Koziolkiewicz M, Stec WJ, Cierniewski CS (2002) DNAzymes to beta 1 and beta 3 mRNA down-regulate expression of the targeted integrins and inhibit endothelial cell capillary tube formation in fibrin and matrigel. $J$ Biol Chem 277: 6779-6787.

Cieslak M, Szymanski J, Adamiak RW, Cierniewski CS (2003) Structural rearrangements of the "10-23" DNAzyme to $\beta 3$ integrin subunit mRNA induced by cations and their relations to the catalytic activity. J Biol Chem 278: 47987-47996.

Dass CR, Choong PF, Khachigian LM (2008a) DNAzyme technology and cancer therapy: cleave and let die. Mol Cancer Ther 7: 243-251.

Dass K, Ahmad A, Azmi AS, Sarkar SH, Sarkar FH (2008b) Evolving role of uPA/uPAR system in human cancers. Cancer Treat Rev 34: 122-136.

Egeblad M, Werb Z (2002) New functions for the matrix metalloproteinases in cancer progression. Nat Rev Cancer 2: 161-174.

Felding-Habermann B, Mueller BM, Romerdahl CA, Cheresh DA (1992) Involvement of integrin alpha $\mathrm{V}$ gene expression in human melanoma tumorigenicity. J Clin Invest 89: 2018-2022.

Fidler IJ, Kumar R, Bielenberg DR, Ellis LM (1998) Molecular determinants of angiogenesis in cancer metastasis. Cancer J Sci Am 4: S58-S66.

Giannelli G, Bergamini C, Fransvea E, Marinosci F, Quaranta V, Antonaci S (2001) Human hepatocellular carcinoma (HCC) cells require both $\alpha 3 \beta 1$ integrin and matrix metalloproteinases activity for migration and invasion. Lab Invest 81: 613-627.

Giannelli G, Astigiano S, Antonaci S, Morini M, Barbieri O, Noonan DM, Albini A (2002) Role of the alpha3beta1 and alpha6beta4 integrins in tumor invasion. Clin Exp Metastasis 19: 217-223.

Goel HL, Li J, Kogan S, Languino LR (2008) Integrins in prostate cancer progression. Endocr Relat Cancer 15: 657-664.

Hanahan D, Weinberg RA (2000) The hallmarks of cancer. Cell 100: 57-70.

Haier J, Nasralla M, Buhr HJ, Nicolson GL (1998) Different integrininduced adhesion of highly liver metastatic and little metastatic colon carcinoma cells in an extracellular matrix. Langenbecks Arch Chir Suppl Kongressbd 115: 307-313.

Hodgkinson CP, Wright MC, Paine AJ (2000) Fibronectin-mediated hepatocyte shape change reprograms cytochrome P450 2C11 gene expression via an integrin-signaled induction of ribonuclease activity. Mol Pharmacol 58: 976-981.

Ise H, Sugihara N, Negishi N, Nikaido T, Akaike T (2001) Low asialoglycoprotein receptor expression as markers for highly proliferative potential hepatocytes. Biochem Biophys Res Commun 285: 172-182.

Jones JC, Hopkinson SB, Goldfinger LE (1998). Hemidesmosomes: extracellular matrix/intermediate filament connectors. BioEssays 20: 488-494.

Kagami S, Kuhara T, Yasutomo K, Okada K, Loster K, Reutter W, Kuroda Y (1996) Transforming growth factor- $\beta$ (TGF- $\beta$ ) stimulates the expression of $\beta 1$ integrins and adhesion by rat mesangial cells. Exp Cell Res 229: 1-6.

Kassis J, Lauffenburger DA, Turner T, Wells A (2001) Tumor invasion as dysregulated cell motility. Semin Cancer Biol 11: 105-117.

Kawakami-Kimura N, Narita T, Ohmori K, Yoneda T, Matsumoto K, Nakamura T, Kannagi R (1997) Involvement of hepatocyte growth factor in increased integrin expression on HepG2 cells triggered by adhesion to endothelial cells. Br J Cancer 75: 47-53.

Kielosto M, Nummela P, Järvinen K, Yin M, Hölttä E (2009) Identification of integrins alpha6 and beta 7 as c-Jun- and transformation- relevant genes in highly invasive fibrosarcoma cells. Int J Cancer 125: 1065-1073.

Kruskal JB, Azouz A, Korideck H, El-Hallak M, Robson SC, Thomas P, Goldberg SN (2007) Hepatic colorectal cancer metastases: imaging initial steps of formation in mice. Radiology 243: 703-711.

Liotta LA, Kohn EC (2001) The microenvironment of the tumourhost interface. Nature (Lond.) 411: 375-379.

Lohi J (2001) Laminin-5 in the progression of carcinomas. Int J Cancer 94: 763-767.

Maglott AP, Bartik S, Cosgun P, Klotz P, Ronde G, Fuhrmann K, Takeda SM, Dontenwill M (2006) The small alpha5beta1 integrin antagonist, SJ749, reduces proliferation and clonogenicity of human astrocytoma cells. Cancer Res 66: 6002-6007.

Mercurio AM, Bachelder RE, Chung J, O'Connor KL, Rabinovitz I, Shaw LM, Tani T (2001) Integrin laminin receptors and breast carcinoma progression. J Mammary Gland Biol Neoplasia 6: 299-309.

Oliva IB, Coelho RM, Barcellos GG, Saldanha-Gama R, Wermelinger LS, Marcinkiewicz C, Zingali B, Barja-Fidalgo C (2007) Effect of RGD-disintegrins on melanoma cell growth and metastasis: involvement of the actin cytoskeleton, FAK and c-Fos. Toxicon 50: 1053-1063.

Papiewska-Pajak I, Antoszczyk S (2006) Regulation of beta1 integrin expression in endothelial cells by chimeric tRNA(Val) ribozyme. Acta Biochim Pol 53: 311-316.

Park CC, Zhang H, Pallavicini M, Gray JW, Baehner F, Park CJ, Bissell MJ (2006) Beta1 integrin inhibitory antibody induces apoptosis of breast cancer cells, inhibits growth, and distinguishes malignant from normal phenotype in three dimensional cultures and in vivo. Cancer Res 66: 1526-1535.

Qian F, Zhang ZC, Wu XF, Li YP, Xu Q (2005) Interaction between integrin alpha(5) and fibronectin is required for metastasis of B16F10 melanoma cells. Biochem Biophys Res Commun 333: 1269_ 1275.

Quaranta V (2002) Motility cues in the tumor microenvironment. Differentiation 70: 590-598.

Radisky D, Hagios C, Bissell MJ (2001) Tumors are unique organs defined by abnormal signaling and context. Semin Cancer Biol 11: 87-95.

Sabherwal Y, Rothman VL, Dimitrov S, L'Heureux DZ, Marcinkiewicz C, Sharma M, Tuszynski GP (2006) Integrin alpha2beta1 mediates the anti-angiogenic and anti-tumor activities of angiocidin, a novel tumor-associated protein. Exp Cell Res 312: 2443-2453.

Sawhney RS, Zhou G-HK, Humphrey LE, Ghosh P, Kreisberg JI, Brattain MG. J (2002) Differences in sensitivity of biological functions mediated by epidermal growth factor receptor activation with respect to endogenous and exogenous ligands. I Biol Chem 277: 75-86.

Schaffert CS, Sorrell MF, Tuma DJ (2001) Expression and cytoskeletal association of integrin subunits is selectively increased in rat perivenous hepatocytes after chronic ethanol administration. Alcohol Clin Exp Res 25: 1749-1757.

Simon-Assmann P, Leberquier C, Molto N, Uezato T, Bouziges F, Kedinger M (1994) Adhesive properties and integrin expression profiles of two colonic cancer populations differing by their spreading on laminin. J Cell Sci 10: 577-587.

Smida Rezgui S, Honore S, Rognoni JB, Martin PM, Penel C (2000) Up-regulation of $\alpha 2 \beta 1$ integrin cell-surface expression protects A431 cells from epidermal growth factor-induced apoptosis. Int J Cancer 87: 360-367.

Stetler-Stevenson WG, Aznavoorian S, Liotta LA (1993) Tumor cell interactions with the extracellular matrix during invasion and metastasis. Annu Rev Cell Biol 9: 541-573.

Torimura T, Ueno T, Kin M, Harad R, Nakamura T, Sakamoto M, Kumashiro R, Yano H, Kojiro M, Sata M (2001) Laminin deposition to type IV collagen enhances haptotaxis, chemokinesis, and adhesion of hepatoma cells through $\beta 1$-integrins. J Hepatol 35: $245-$ 253.

Yao ES, Zhang H, Chen YY, Lee B, Chew K, Moore D, Park C (2007) Increased B1 integrin is associated with decreased survival in invasive breast cancer. Cancer Res 67: 659-664.

Yuan ST, Hu XQ, Lu JP, KeiKi H, Zhai WR, Zhang YE (2000) Changes of integrin expression in rat hepatocarcinogenesis induced by 3'-Me-DAB. World J Gastroenterol 6: 231-233.

Zeng ZZ, Jia Y, Hahn NJ, Markwart SM, Rockwood KF, Livant DL (2006) Role of focal adhesion kinase and phosphatidylinositol 3'-kinase in integrin fibronectin receptor-mediated, matrix metalloproteinase-1-dependent invasion by metastatic prostate cancer cells. Cancer Res 66: 8091-8099. 